\title{
Pengaruh persepsi harga, kontrol diri, dan literasi ekonomi terhadap perilaku pembelian impulsif produk baju pada mahasiswa S1 pendidikan ekonomi Universitas Negeri Malang angkatan 2017
}

\author{
Intan Dewanti, Agung Haryono* \\ Universitas Negeri Malang, Jl. Semarang No. 5 Malang, Jawa Timur, Indonesia \\ *Penulis korespondensi, Surel: agung.haryono.fe@um.ac.id
}

Paper received: 6-8-2021; revised: 20-8-2021; accepted: 28-8-2021

\begin{abstract}
Impulsive buying behavior is buying behavior based on sudden desire without any consideration or planning. This research aims to determine the effect of price perception, self-control, and economic literacy on the impulsive buying behaviour of the students of S1 Economic Education, State University of Malang in academic 2017. Data collection techniques used questionnaires and tests. The results showed that: (1) there was a negative and significant effect of perceived price on the impulsive buying behavior of clothing products with an effective contribution of $25.65 \%$. (2) There was a negative and significant effect of self-control on impulsive buying behavior for clothing products with an effective contribution of $23.34 \%$. (3) There was a negative and significant effect of economic literacy on impulsive buying behavior for clothing products with an effective contribution of $12.57 \%$.
\end{abstract}

Keywords: price perception; self-control; economic literacy and impulsive buying behavior.

\begin{abstract}
Abstrak
Perilaku pembelian impulsif adalah perilaku pembelian yang terjadi karena didasari keinginan secara tiba-tiba tanpa suatu pertimbangan atau perencanaan sebelumnya.Penelitian ini bertujuan untuk mengetahui pengaruh persepsi harga, kontrol diri, dan literasi ekonomi terhadap perilaku pembelian impulsif produk baju mahasiswa S1 Pendidikan Ekonomi Universitas Negeri Malang angkatan 2017. Teknik pengumpulan data menggunakan angket dan tes. Hasil penelitian menunjukkan bahwa: (1) Terdapat pengaruh negatif dan signifikan persepsi harga terhadap perilaku pembelian impulsif produk baju dengan sumbangan efektif sebesar 25,65\%. (2) Terdapat pengaruh negatif dan signifikan kontrol diri terhadap perilaku pembelian impulsif produk baju dengan sumbangan efektif sebesar 23,34\%. (3) Terdapat pengaruh negatif dan signifikan literasi ekonomi terhadap perilaku pembelian impulsif produk baju dengan sumbangan efektif $12,57 \%$.
\end{abstract}

Kata kunci: persepsi harga; kontrol diri; literasi ekonomi dan perilaku pembelian impulsif.

\section{Pendahuluan}

Maraknya pusat perbelanjaan yang ada disertai kemudahan akses menuju tempat perbelanjaan memudahkan konsumen dalam melakukan pembelian. Terlebih pada masa sekarang perubahan zaman yang semakin modern membuat semua kalangan mengikuti arus trend yang ada. Produk yang selalu mengalami perubahan trend dengan cepat adalah model baju, hal tersebut berdampak pada keinginan konsumen untuk melakukan pembelian agar terlihat modern. Keinginan tersebut membuat konsumen melakukan pembelian tanpa mempertimbangkan kebutuhan utama sehingga menimbulkan perilaku pembelian impulsif atau pembelian tanpa perencanaan hanya karena keinginan sesaat. Perilaku pembelian impulsif biasa terjadi ketika masuk dalam pusat perbelanjaan dimana pada saat dari rumah 
sebenarnya tidak ada rencana ataupun tujuan melakukan pembelian produk. Menurut teori Rook dan Fisher perilaku pembelian impulsif menyebabkan konsumen menjadi tidak rasional dalam melakukan pembelian karena keinginan pembelian tersebut terjadi secara otomatis, spontan, reflek dan tiba-tiba pada saat konsumen melihat suatu tampilan produk. Sejalan dengan itu menurut teori clover pembelian impulsif merupakan pembelian yang memiliki beberapa dimensi yaitu keterkaitan, posesif produk, melupakan akibat pembelian serta konflik diri. Menurut Hetharie (2013:892) perilaku pembelian impulsif dianggap pembelian negatif dari pada sesuatu yang baik, hal tersebut disebabkan pembelian impulsif terjadi secara cepat, mendadak, reflek, lebih mengarahkan perilaku emosional dibandingkan rasionalitas, serta konsumen akan "out of control'ketika sedang mengalami pembelian barang secara impulsif. Tanpa disadari perilaku pembelian impulsif ini terjadi tanpa pertimbangan yang matang dan muncul disertai desakan hati yang tiba-tiba penuh dengan kekuatan untuk melakukan pembelian tanpa memperhatikan akibat yang akan ditimbulkan. Pembelian impulsif akan merugikan pelakunya karena lebih mengarah pada dampak negatif dari pada dampak positif. Dampak yang ditimbulkan akan merugikan diri sendiri misalnya pengelolaan keuangan menjadi tidak tertata dengan baik dan pengeluaran yang dilakukan tidak sesuai dengan rencana.

Perilaku pembelian impulsif banyak ditemukan pada mahasiswa, karena mahasiswa telah mendapatkan kepercayaan untuk mengatur keuangannya sendiri. Hal tersebut sejalan dengan Pratiwi (2017:99) menurutnya remaja tingkat akhir yaitu mahasiswa, mereka menampakkan ciri mudah terpengaruh tawaran iklan, kurang berpikir hematnya membeli, cepat dipengaruhi pedagang, kurang berpikir sesuai realitas, emosionalnya yang kuat serta tidak sukar untuk terpengaruh (impulsif). Mereka melakukan pembelian karena ingin terlihat modern dan sama dengan lingkup pergaulannya. Oleh karena itu mahasiswa bisa dikatakan termasuk dalam kalangan yang mudah tergiur tawaran produk seperti produk baju yang setiap waktu mengalami perubahan trend terbaru. Menurut Oktavia (2019:7) remaja tingkat akhir dikatakan mudah terkena dampak impulsif dalam pembelian karena mahasiswa seringkali mengikuti arus trend yang sedang ada untuk terlihat up to date serta mempunyai keinginan yang besar untuk segera membeli barang.

Pembelian yang dilakukan secara impulsif secara reflek terjadi pada saat konsumen dihadapkan oleh suatu produk, hal tersebut terjadi karena tanggapan mereka dalam menilai suatu produk tersebut. Salah satu aspek yang dijadikan penilaian melakukan pembelian adalah persepsi konsumen terhadap harga dari suatu produk. Pada kenyataanya setiap konsumen tentu mempunyai persepsi berbeda dalam menilai harga. Harga memiliki peranan dalam mengarahkan konsumen melakukan pembelian, yaitu sebagai pengarah bahwa harga produk yang akan dibeli selaras pada daya beli serta manfaatnya dan harga produk yang mereka beli memiliki kualitas yang sesuai. Persepsi harga adalah tanggapan terhadap informasi harga yang tersedia dimana nantinya akan dijadikan bahan pertimbangan konsumen untuk pembeliannya. Sejalan dengan pendapat Peter dan Olson (2010:447) persepsi harga merupakan tanggapan konsumen akan informasi harga dan menjadikannya kesan mendalam sehingga dijadikan bahan acuan melakukan pembelian. Melalui persepsi harga konsumen akan memiliki beberapa pertimbangan dalam melakukan pembelian. Namun yang biasa terjadi informasi harga yang ditawarkan seringkali membuat konsumen bertindak impulsif. Beberapa bentuk tawaran seperti potongan harga, pembelian dengan tambahan bonus dan tampilan produk yang menarik. Melalui tawaran-tawaran tersebut akan memunculkan dorongan untuk melakukan pembelian. Konsumen akan terpancing untuk mendapatkan produk tersebut meskipun 
sebelumnya tidak memiliki rencana untuk membelinya, namun karena tawaran harga suatu produk konsumen akan terpengaruh melakukan pembelian impulsif tanpa melalui pertimbangan-pertimbangan.

Pada kenyataanya perilaku pembelian secara impulsif terjadi alamiah dengan didasari ketertarikan pada produk tanpa memikirkan akibat yang ada selanjutnya. Konsumen tidak berpikir apakah produk yang mereka beli merupakan kebutuhan atau hanya keinginan sesaat. Oleh karena itu dibutuhkan pengendalian diri atau kontrol diri agar tetap berperilaku rasional dalam pembelian. Disini kontrol diri akan berperan untuk menentukan pilihan-pilihan apa yang diambil dalam melakukan suatu tindakan. Kontrol diri merupakan suatu pengontrolan perilaku yang berhubungan pada bagaimana cara seseorang mengatur emosionalnya dan desakan yang ada pada individu tersebut. Menurut Hoyri (2014:52) mengungkapkan pengendalian diri adalah keahlian dalam mengendalikan tingkah laku berdasarkan standar tertentu dengan tujuan untuk mengarahkan pada perilaku positif. Namun setiap konsumen memiliki tingkat pengendalian diri yang berbeda-beda. Konsumen yang mempunyai kontrol diri, lebih mampu mengendalikan dirinya dan menekan keinginannya melakukan pembelian impulsif. Sebaliknya dengan rendahnya kontrol diri akan lebih mengarahkan pada kegiatan pembelian yang impulsif tanpa pengendalian diri. Hal tersebut sejalan dengan Haryani dan Herwanto (2015:7) menurut pendapatnya dengan kontrol diri yang dimiliki, individu akan mampu menahan dan menghalangi impuls-impuls atau perilaku yang impulsif.

Pembelian yang terjadi secara impulsif akan mudah didapati pada pusat perbelanjaan seperti mall, distro atau pasar. Konsumen yang biasa mengunjungi pusat perbelanjaan adalah remaja terutama mahasiswa. Pada pergaulan mahasiswa saat ini, aktivitas berbelanja atau hanya sekedar mengunjungi pusat perbelanjaan merupakan kegiatan yang sedang trend. Ketika mereka melakukan kunjungan pada tempat-tempat tersebut dan melihat produk yang menarik maka besar kemungkinan akan timbul perilaku pembelian impulsif. Hal yang bisa dijadikan acuan dalam mengontrol perilaku pembelian impulsif adalah pengetahuan dasar ekonomi yang tertanam kuat agar tetap berperilaku rasional. Melalui pengetahuan dasar ekonomi akan menanamkan perilaku pembelian yang tepat dan mengesampingkan keinginan yang kurang penting sehingga tidak terjerat dalam perilaku pembelian impulsif atau pembelian spontan. Melalui pengetahuan dasar ekonomi maka akan terbentuk pemahaman tentang konsep ekonomi yang benar atau literasi ekonomi. Menurut Oktavia (2019:3) Literasi ekonomi adalah istilah yang menjelaskan kemampuan seseorang dalam mengidentifikasi konsep ekonomi dengan berpikir kritis di bidang ekonomi dengan tujuan meningkatkan kesejahteraan. Jadi literasi ekonomi adalah bentuk metode penerapan pada rangkaian pembelajaran yang dapat dipakai mahasiswa menjadi konsumen yang rasional. Dengan literasi ekonomi mahasiswa akan diberikan pembelajaran cara yang tepat dalam membuat pilihan yang rasional terutama dalam mengontrol pembelian. Apabila konsumen sudah mampu mengontrol pembelian dengan didasari literasi ekonomi yang kuat maka besar kemungkinan untuk tidak melakukan pembelian impulsif. Namun ketika literasi ekonomi yang tertanam kurang maka besar kemungkinan konsumen tersebut akan mudah terpengaruh oleh suatu produk tanpa memikirkan rasionalitas pembelian sehingga akan mudah melakukan perilaku pembelian impulsif.

Menurut Setyaningrum dan Harsono (2018) literasi ekonomi adalah pengetahuan utama ekonomi yang dimiliki individu seperti bagaimana perekonomiannya mampu berjalan tepat dan baik dari sisi keputusannya maupun kegiatannya yang berkesinambungan pada aspek 
ekonomi. Oleh karena itu setiap individu yang sudah memiliki literasi ekonomi seharusnya dapat mengontrol keuangan dengan baik dan mampu mengatasi masalah-masalah ekonomi yang dihadapi serta bertindak sesuai ilmu ekonomi. Dari penjelasan dan permasalahanpermasalahan tersebut peneliti ingin membuktikan apakah persepsi harga, kontrol diri, dan literasi ekonomi akan berpengaruh terhadap perilaku pembelian impulsif. Berdasarkan uraian tersebut, peneliti tertarik untuk melakukan penelitian dengan judul "Pengaruh Persepsi Harga, Kontrol Diri, Dan Literasi Ekonomi Terhadap Perilaku Pembelian Impulsif Produk Baju Pada Mahasiswa S1 Pendidikan Ekonomi Universitas Negeri Malang Angkatan 2017". Persepsi harga merupakan tanggapan konsumen akan informasi harga yang diterima dan memberikan makna serta penilaian yang mendalam bagi mereka sehingga mampu memunculkan keinginan pembelian (Kusdyah, 26:2012). Keahlian seseorang untuk mengatur dirinya dalam bertingkah laku dengan terbebas dari hambatan merupakan sebuah kontrol diri atau pengendalian diri (Thalib, 2017). Literasi ekonomi merupakan pemahaman menggunakan konsep ekonomi dasar dalam pengambilan keputusan ekonomi (Murniatiningsih, 2017). Sedangkan perilaku pembelian yang terjadi impulsif adalah pembelian reflek pada saat dihadapkan suatu produk tanpa ada perencanaan pembelian sebelumnya (Lisda, 2010).

\section{Metode}

Pendekatan yang digunakan dalam penelitian ini adalah pendekatan kuantitatif dengan jenis eksplanasi. Sumber data yang digunakan dalam penelitian ini adalah data primer dan sekunder. Data primer didapatkan langsung dari responden melalui pengisian instrumen penelitian, sedangkan data sekunder didapatkan dari dokumentasi arsip pada fakultas ekonomi mengenai jumlah mahasiswa S1 Pendidikan Ekonomi angkatan 2017. Berdasarkan data yang didapatkan, populasi dalam penelitian ini terdiri dari 137 mahasiswa S1 Pendidikan Ekonomi Universitas Negeri Malang Angkatan 2017. Sampel dalam penelitian ini adalah 102 mahasiswa yang diambil menggunakan teknik Proportional Random Sampling menggunakan rumus Slovin. Instrumen penelitian yang digunakan adalah angket dan tes yang disebarkan melalui google form yang dilaksanakan pada bulan Maret-April tahun 2021. Data yang digunakan dalam angket adalah variabel bebas persepsi harga $\left(\mathrm{X}_{1}\right)$ yang terdiri dari 10 butir pertanyaan, kontrol diri $\left(\mathrm{X}_{2}\right)$ yang terdiri dari 10 butir pertanyaan dan variabel terikat perilaku pembelian impulsif $(\mathrm{Y})$ yang terdiri dari 15 butir pertanyaan. Sedangkan data yang digunakan dalam tes adalah variabel bebas literasi ekonomi $\left(\mathrm{X}_{3}\right)$ yang terdiri dari 10 butir pertanyaan. Instrumen harus melewati proses pengujian sebelum digunakan dalam penelitian. Sebuah instrumen yang baik harus memenuhi uji validitas dan uji reliabilitas. Uji validitas digunakan untuk mengukur valid atau tidaknya suatu angket, apabila skor item yang ada dalam angket terbukti mempunyai korelasi positif yang signifikan dengan skor totalnya, maka sebutir item tersebut sudah valid. Sedangkan uji reliabilitas merupakan uji instrumen yang digunakan untuk mengetahui sejauh mana hasil pengukuran dapat dipercaya. Pada penelitian ini pengujian instrumen menggunakan IBM SPSS Statistic 25. Langkah selanjutnya dalam penelitian ini adalah analisis, antara lain yaitu, 1) analisis regresi linier berganda. 2) Uji asumsi klasik yaitu terdiri dari uji normalitas, uji multikolinearitas, dan uji heteroskedastisitas. 3) Uji hipotesis mempunyai dua uji yaitu uji t dan uji F. 4) sumbangan efektif 5) koefisien determinasi atau $\mathrm{R}^{2}$. 
Jurnal Ekonomi, Bisnis dan Pendidikan, 1(8), 2021, 718-734

\section{Hasil dan Pembahasan}

Tabel 1. Hasil Analisis Regresi Linier Berganda

\begin{tabular}{|c|c|c|c|c|c|c|}
\hline \multicolumn{7}{|c|}{ Coefficients $^{\mathbf{a}}$} \\
\hline \multirow[b]{2}{*}{ Model } & & \multicolumn{2}{|c|}{ Unstandardized Coefficients } & \multirow{2}{*}{$\begin{array}{l}\text { Standardized } \\
\text { Coefficients } \\
\text { Beta }\end{array}$} & \multirow[b]{2}{*}{$\mathrm{T}$} & \multirow[b]{2}{*}{ Sig. } \\
\hline & & $\mathrm{B}$ & Std. Error & & & \\
\hline \multirow[t]{4}{*}{1} & (Constant) & 74.586 & 2.600 & & 28.691 & .000 \\
\hline & Persepsi Harga & -.455 & .132 & -.355 & -3.449 & .001 \\
\hline & Kontrol Diri & -.419 & .130 & -.327 & -3.210 & .002 \\
\hline & Literasi Ekonomi & -.983 & .321 & -.225 & -3.062 & .003 \\
\hline
\end{tabular}

a. Dependent Variable: Perilaku Pembelian Impulsif

Hasil analisis regresi berganda persamaannya yang sesuai dengan tabel 1 dapat disusun seperti persamaan dibawah ini.

$$
\begin{aligned}
& Y=\beta_{0}+\beta_{1} X_{1}+\beta_{2} X_{2}+\beta_{3} X_{3}+e \\
& Y=74.586+(-0,445) \times 1+(-0,419) \times 2+(-0,983) \times 3
\end{aligned}
$$

Keterangan:

$\mathrm{Y} \quad=$ Perilaku Pembelian Impulsif Produk Baju

$\alpha=$ Konstanta

$\beta 1 \beta 2=$ Koefisien Regresi

$\mathrm{X} 1=$ Persepsi Harga

$\mathrm{X} 2=$ Kontrol Diri

$\mathrm{X} 3=$ Literasi Ekonomi

$\alpha$ merupakan konstanta dengan nilai 74.586 yang artinya apabila variabel independen dianggap konstan atau jika persepsi harga, kontrol diri, dan literasi ekonomi berubah 0 satuan maka besarnya variabel perilaku pembelian impulsif produk baju (Y) sebesar 74.586.

$\beta_{1}$ merupakan nilai koefisien regresi untuk variabel persepsi harga $\left(\mathrm{X}_{1}\right)$ yang artinya jika nilai koefisien $\mathrm{X}_{1}$ mengalami kenaikan sebesar 1 satuan maka perilaku pembelian impulsif produk baju akan berkurang sejumlah 0,455 dan asumsinya variabel lainnya tetap.

$\beta_{2}$ merupakan nilai koefisien regresi untuk variabel kontrol diri $\left(\mathrm{X}_{2}\right)$ yang artinya jika nilai koefisien $X_{1}$ mengalami kenaikan sebesar 1 satuan maka perilaku pembelian impulsif produk baju akan berkurang sejumlah 0,419 dan asumsinya variabel lainnya tetap.

$\beta_{3}$ merupakan nilai koefisien regresi untuk variabel literasi ekonomi $\left(\mathrm{X}_{3}\right)$ yang artinya jika nilai koefisien $\mathrm{X}_{3}$ mengalami kenaikan sejumlah 1 satuan maka perilaku pembelian impulsif produk baju menjadi menurun senilai 0,983 dan asumsinya variabel lainnya tetap.

e ialah prediksi kesalahan pada persamaan regresi yang diakibatkan adanya pengaruh lainnya pada variabel bebas (X) yang berpengaruh pada variabel terikat (Y) namun tanpa dimasukkan dalam persamaan regresi.

\section{Tabel 2. Hasil Uji Normalitas}


Jurnal Ekonomi, Bisnis dan Pendidikan, 1(8), 2021, 718-734

One-Sample Kolmogorov-Smirnov Test

\begin{tabular}{|c|c|c|c|c|c|}
\hline & & $\begin{array}{l}\text { Persepsi } \\
\text { Harga }\end{array}$ & $\begin{array}{l}\text { Kontrol } \\
\text { Diri }\end{array}$ & $\begin{array}{l}\text { Literasi } \\
\text { Ekonomi }\end{array}$ & $\begin{array}{l}\text { Perilaku } \\
\text { Pembelian } \\
\text { Impulsif }\end{array}$ \\
\hline \multicolumn{2}{|l|}{$\mathrm{N}$} & 102 & 102 & 102 & 102 \\
\hline \multirow{2}{*}{$\begin{array}{l}\text { Normal } \\
\text { Parametersa,,b }\end{array}$} & Mean & 28.62 & 27.67 & 6.75 & 43.36 \\
\hline & Std. Deviation & 8.925 & 8.910 & 2.613 & 11.424 \\
\hline \multirow{3}{*}{$\begin{array}{l}\text { Most Extreme } \\
\text { Differences }\end{array}$} & Absolute & .159 & .099 & .234 & .183 \\
\hline & Positive & .100 & .099 & .138 & .100 \\
\hline & Negative & -.159 & -.093 & -.234 & -.183 \\
\hline \multicolumn{2}{|c|}{ Kolmogorov-Smirnov Z } & .698 & .999 & .927 & .688 \\
\hline \multicolumn{2}{|c|}{ Asymp. Sig. (2-tailed) } & .714 & .271 & .357 & .732 \\
\hline \multicolumn{6}{|c|}{ a. Test distribution is Normal. } \\
\hline \multicolumn{6}{|c|}{ b. Calculated from data. } \\
\hline
\end{tabular}

Selaras dengan hasil uji normalitas pada tabel 2 diatas, diketahui bahwa uji normalitas tujuannya merupakan melakukan pengujian pada bentuk model regresi, yaitu variabel dependen dan variabel independen memiliki data yang normal atau tidak normal. Pengujian yang digunakan adalah Kolmogorov Smirnov, dengan kriterianya yaitu Asymp. Sig (2- tailed) lebih tinggi dari taraf signifikansi $(\alpha=0,05)$ dikatakan datanya distribusinya normal. Sesuai pemaparan tabel 2 menerangkan apabila nilai Asymp. Sig. (2-tailed) variabel persepsi harga sejumlah 0,714, kontrol diri sejumlah 0,271, literasi ekonomi sejumlah 0,357, dan perilaku pembelian impulsif sejumlah 0,732. Setiap variabel mempunyai nilai signifikansi $>0,05$ sehingga menunjukkan bahwa seluruh data memiliki distribusi yang normal.

Tabel 3. Hasil Uji Multikolinearitas

\begin{tabular}{llll}
\multicolumn{3}{c}{ Coefficients $^{\mathbf{a}}$} \\
\hline \multirow{2}{*}{ Model } & & \multicolumn{2}{l}{ Collinearity Statistics } \\
\cline { 3 - 4 } 1 & Persepsi Harga & Tolerance & VIF \\
\hline & Kontrol Diri & .983 & 1.017 \\
& Literasi Ekonomi & .994 & 1.006 \\
& & .987 & 1.014 \\
\hline
\end{tabular}

a. Dependent Variable: Perilaku Pembelian Impulsif

Pengujian multikolinieritas sesuai dengan tabel 3 dipergunakan untuk mengetahui ada atau tidaknya hubungan variabel independen satu dengan lainnya dari model regresi berganda. Selaras dengan tabel 3 hasil uji multikolinieritas pada penelitian ini memaparkan hasil yaitu nilai VIF variabel persepsi harga sejumlah (1,017), variabel kontrol diri sejumlah(1,006), dan variabel literasi ekonomi sejumlah $(1,014)$. Selanjutnya nilai tolerance variabel persepsi harga sebesar $(0,983)$, variabel kontrol diri sebesar $(0,994)$, dan variabel literasi ekonomi sebesar $(0,987)$. Oleh karena itu dapat dijelaskan apabila VIF untuk seluruh variabel < 10 serta nilai Tolerance pada seluruh variabel $>10$, sehingga kesimpulanya adalah bentuk regresi pada penelitian ini tidak ada gejala multikolinieritas. 
Tabel 4. Uji Heteroskedastisitas

\begin{tabular}{|c|c|c|c|c|c|c|}
\hline \multicolumn{7}{|c|}{ Coefficients ${ }^{\mathbf{a}}$} \\
\hline \multirow[b]{2}{*}{ Model } & & \multicolumn{2}{|c|}{ Unstandardized Coefficients } & \multirow{2}{*}{$\begin{array}{l}\text { Standardiz } \\
\text { ed } \\
\text { Coefficients } \\
\text { Beta }\end{array}$} & \multirow[b]{2}{*}{$\mathrm{T}$} & \multirow[b]{2}{*}{ Sig. } \\
\hline & & $\mathrm{B}$ & Std. Error & & & \\
\hline \multirow[t]{4}{*}{1} & (Constant) & 42.161 & 8.649 & & 4.874 & .000 \\
\hline & Persepsi Harga & -.148 & .441 & -.053 & -.335 & .739 \\
\hline & Kontrol Diri & -.328 & .442 & -.118 & -.743 & .460 \\
\hline & $\begin{array}{l}\text { Literasi } \\
\text { Ekonomi }\end{array}$ & -.406 & .379 & -.106 & -1.072 & .286 \\
\hline
\end{tabular}

a. Dependent Variable: absresid

Uji heteroskedastisitas sesuai tabel 4 dipergunakan untuk mengetahui apakah dalam model regresi terdeteksi ketidaksamaan varian dari residual satu pengamatan ke pengamatan lainnya. Apabila ada kesamaan atau nilainya tetap pada nilai residual satu ke pengamatan lainya maka dikatakan homohomokedasteisitas. Namun apabila terjadi perbedaan varian pada satu pengamatan ke pengamatan lainnya dikatakan heteroskedastisitas. Dapat dikatakan baik suatu model regresi apabila tidak terdeteksi heteroskedastisitas. Pada penelitian ini uji heteroskedastisitas mempergunakan uji Glejser yang sesuai dengan tabel 4 diatas yang memaparkan bilamana untuk nilai signifikan variabel persepsi harga sejumlah 0,739, nilai signifikansi variabel kontrol sejumlah 0,460, dan nilai signifikansi variabel literasi ekonomi sejumlah 0,286. Selaras melalui pemaparan diatas dapat disimpulkan apabila semua variabel mempunyai nilai signifikansi $>0,05$, dimana artinya dalam penelitian ini data yang dipergunakan bebas dari heteroskedastisitas.

Tabel 5. Uji Parsial (Uji t)

\begin{tabular}{|c|c|c|c|c|c|c|}
\hline \multicolumn{7}{|c|}{ Coefficients $^{a}$} \\
\hline \multirow[b]{2}{*}{ Model } & & \multicolumn{2}{|c|}{ Unstandardized Coefficients } & \multirow{2}{*}{$\begin{array}{l}\text { Standardized } \\
\text { Coefficients } \\
\text { Beta }\end{array}$} & \multirow[b]{2}{*}{$\mathrm{t}$} & \multirow[b]{2}{*}{ Sig. } \\
\hline & & $\mathrm{B}$ & Std. Error & & & \\
\hline \multirow[t]{4}{*}{1} & (Constant) & 74.586 & 2.600 & & 28.691 & .000 \\
\hline & Persepsi Harga & -.455 & .132 & -.355 & -3.449 & .001 \\
\hline & Kontrol Diri & -.419 & .130 & -.327 & -3.210 & .002 \\
\hline & Literasi Ekonomi & -.983 & .321 & -.225 & -3.062 & .003 \\
\hline
\end{tabular}

a. Dependent Variable: Perilaku Pembelian Impulsif

Selaras dengan tabel 5 uji t dipergunakan mengetahui pengaruh variabel independen terhadap variabel dependen, bisa juga dikatakan untuk mempertunjukkan seberapa besar variabel independen secara individual dalam menjelaskan variabel dependen yaitu dengan anggapan variabel bebas yang lain merupakan tetap atau konstan. Sesuai tabel 3.9 penelitian ini uji hasilnya memaparkan sebagai berikut, 1)Variabel persepsi harga mempunyai nilai signifikansi sejumlah 0,001, maka hal ini ditunjukkan apabila nilai signifikansi $<0,05$, kesimpulannya adalah $\mathrm{H}_{0}$ ditolak dan $\mathrm{H}_{1}$ diterima. Pada variabel persepsi harga nilai $t_{\text {hitung }}$ adalah sejumlah $-3,499$, untuk nilai $t_{\text {tabel }}$ diketahui 1,98 oleh karena itu kesimpulannya adalah 
$\mathrm{H}_{0}$ ditolak $\mathrm{H}_{1}$ diterima. Hasil uji parsial variabel persepsi harga maka kesimpulanya dinyatakan adanya pengaruh negatif antara persepsi harga dengan perilaku pembelian impulsif produk baju mahasiswa S1 Pendidikan Ekonomi Universitas Negeri Malang Angkatan 2017. 2) Variabel kontrol diri mempunyai nilai signifikansi sejumlah 0,002, maka hal ini ditunjukkan apabila nilai signifikansi $<0,05$, kesimpulannya adalah $\mathrm{H}_{0}$ ditolak $\mathrm{H}_{1}$ diterima. Pada variabel kontrol diri nilai thitung adalah sejumlah $-3,210$, untuk nilai tabel diketahui 1,98 oleh karena itu kesimpulannya adalah $\mathrm{H}_{0}$ ditolak $\mathrm{H}_{1}$ diterima. Hasil uji parsial variabel kontrol diri maka kesimpulannya dinyatakan adanya pengaruh negatif antara kontrol diri dengan perilaku pembelian impulsif produk baju mahasiswa S1 Pendidikan Ekonomi Universitas Negeri Malang Angkatan 2017. 3) Variabel literasi ekonomi mempunyai nilai signifikansi sejumlah 0,003, maka hal ini ditunjukkan apabila nilai signifikansi $<0,05$, kesimpulannya adalah $\mathrm{H}_{0}$ ditolak $\mathrm{H}_{1}$ diterima. Pada variabel literasi ekonomi nilai $t_{\text {hitung }}$ adalah sejumlah $-3,026$, untuk nilai $t_{\text {tabel }}$ diketahui 1,98 oleh karena itu kesimpulannya adalah $\mathrm{H}_{0}$ ditolak $\mathrm{H}_{1}$ diterima. Hasil uji parsial literasi ekonomi maka kesimpulannya dinyatakan adanya pengaruh negatif antara literasi ekonomi dengan perilaku pembelian impulsif produk baju mahasiswa S1 Pendidikan Ekonomi Universitas Negeri Malang Angkatan 2017.

Tabel 6. Uji Simultan (Uji F)

\begin{tabular}{lllllll}
\multicolumn{7}{c}{ ANOVA $^{\mathbf{b}}$} \\
Model & & Sum of Squares & Df & Mean Square & F & Sig. \\
\hline 1 & Regression & 8101.781 & 3 & 2700.594 & 52.100 & $.000^{\text {a }}$ \\
& Residual & 5079.798 & 98 & 51.835 & & \\
& Total & 13181.578 & 101 & & & \\
\hline
\end{tabular}

a. Predictors: (Constant), Literasi Ekonomi, Kontrol Diri, Persepsi Harga

b. Dependent Variable: Perilaku Pembelian Impulsif

Uji $F$ selaras dengan tabel 6 dipergunakan untuk mengetahui terdapat atau tidak terdapat pengaruh pada variabel independen secara simultan. Pengujian pada penelitian ini yaitu uji F didapatkan bahwa nilai Sig sejumlah 0,000 yang artinya bahwa nilai $\operatorname{Sig}<0,05$. Dapat diketahui nilai $F_{\text {hitung }}$ sejumlah 52,100 serta nilai $F_{\text {tabel }}$ sejumlah 2,70 yang artinya bahwa $\mathrm{F}_{\text {hitung }}>\mathrm{F}_{\text {tabel.. }}$ Kesimpulannya adalah $\mathrm{H}_{0}$ ditolak $\mathrm{H}_{1}$ diterima, oleh karena itu persepsi harga $\left(\mathrm{X}_{1}\right)$, kontrol diri $\left(\mathrm{X}_{2}\right)$, dan literasi ekonomi $\left(\mathrm{X}_{3}\right)$ mempunyai pengaruh secara simultan dengan perilaku pembelian impulsif produk baju (Y) pada mahasiswa S1 Pendidikan Ekonomi Universitas Negeri Malang Angkatan 2017.

Tabel 7. Sumbangan efektif

\begin{tabular}{llll}
\hline Variabel & Zero Order & Beta & Sumbangan Efektif \\
\hline$X_{1}$ & $-0,722$ & $-0,355$ & $25,65 \%$ \\
$X_{2}$ & $-0,712$ & $-0,327$ & $23,24 \%$ \\
$X_{3}$ & $-0,559$ & $-0,225$ & $12,57 \%$ \\
& Jumlah & & $61,46 \%$ \\
\hline
\end{tabular}

Selaras dengan tabel 7 penggunaan sumbangan efektif yaitu bertujuan mengetahui banyaknya sumbangan pada setiap variabel, yaitu pada variabel independen dan variabel dependen dengan menggunakan coefficients beta dan zero order dari tiap variabel. Dapat 
diketahui hasil sumbangan efektif sesuai tabel 7 yaitu bahwa nilai beta untuk $\mathrm{X}_{1}$ sejumlah 0,355, $X_{2}$ sejumlah -0,327, dan $X_{3}$ sejumlah -0,225.Nilai Zero- order untuk $X_{1}$ sejumlah-0,722, $X_{2}$ sejumlah -0,712, dan $X_{3}$ sejumlah -0,559. Sumbangan efektif dari masing-masing variabel dapat dihitung dengan cara mengalikan (Zero Order x Koefisien Beta x 100\%.). Berdasarkan hasil perhitungan sumbangan efektif menunjukkan bahwa persentase sumbangan efektif $\mathrm{X}_{1}$ sejumlah $25,65 \%$, $X_{2}$ sejumlah $23,24 \%$, dan $X_{3}$ sejumlah $12,57 \%$. Sejalan dengan hasil yang ada dapat disimpulkan bahwa variabel dependen yang paling berpengaruh atau pengaruhnya tinggi dengan perilaku pembelian impulsif produk baju mahasiswa S1 Pendidikan Ekonomi Universitas Negeri Malang Angkatan 2017 merupakan variabel persepsi harga $\left(\mathrm{X}_{1}\right)$ dengan sumbangan efektif sebesar 25,65\%.

\section{Tabel 8. Koefisien Determinasi}

\begin{tabular}{lllll}
\hline \multicolumn{5}{c}{ Model Summary } \\
\hline Model & $\mathrm{R}$ & R Square & Adjusted R Square & Std. Error of the Estimate \\
\hline 1 & $.784^{\mathrm{a}}$ & .615 & .603 & 7.200 \\
\hline
\end{tabular}

a. Predictors: (Constant), Literasi Ekonomi, Kontrol Diri, Persepsi Harga

b. Dependent Variable: Perilaku Pembelian Impulsif

Koefisien determinasi yang selaras dengan tabel 8 dipergunakan dalam mencari seberapa tingginya kemampuan pada variabel independen untuk menjelaskan variabel dependen. Dalam penghitungan koefisien determinasi didapatkan bahwa nilai koefisien determinasi $\left(\mathrm{R}^{2}\right)$ variabel persepsi harga, kontrol diri, dan literasi ekonomi secara bersamasama terhadap perilaku pembelian impulsif adalah sebesar 0,615 x 100\% $=61,5 \%$. Oleh karena itu kesimpulannya adalah secara simultan persepsi harga, kontrol diri, dan literasi mempengaruhi perilaku pembelian impulsif sejumlah sebesar 61,5\%. Jadi dapat diketahui bahwa ada faktor lain yang mempengaruhi variabel perilaku pembelian impulsif yang jumlahnya $38,5 \%$

\subsection{Pengaruh Persepsi Harga Terhadap Perilaku Pembelian Impulsif Produk Baju Pada Mahasiswa S1 Pendidikan Ekonomi Universitas Negeri Malang Angkatan 2017}

Penelitian ini menerangkan hasil bahwa persepsi harga memiliki pengaruh yang signifikan serta bernilai negatif dengan perilaku pembelian impulsif produk baju, yang artinya ketika mahasiswa memiliki persepsi harga yang baik, maka perilaku pembelian impulsif terhadap baju cenderung rendah hal ini disebabkan karena mahasiswa mampu menganalisis harga dengan tepat sesuai dengan pandangan yang bersifat rasional. Hal tersebut sejalan dengan pernyataan Harjati dan Venesia (2015:160) bahwa persepsi harga yaitu rangkaian kegiatan penyeleksian, pengorganisasian, serta pengartian stimulus tentang informasi suatu harga yang dijadikan refleksi atau representasi untuk melakukan pembelian atau sudut pandang konsumen dalam memandang harga dimana harga tersebut mahal, murah atau masuk akal serta terjangkau. Jadi persepsi harga memiliki hubungan yang tinggi apabila dikaitkan dengan keinginan melakukan pembelian serta dapat dikaitkan dengan cara konsumen dalam memahami secara mendalam informasi tentang harga yang nantinya akan memberikan kesan yang bermakna bagi konsumen tersebut. 
Bahwasanya berdasarkan hasil deskriptif data penelitian mahasiswa S1 Pendidikan Ekonomi tergolong baik. Hal tersebut terlihat pada mahasiswa yang berpersepsi tentang harga dengan baik pada saat akan membeli produk baju tingkat selektifitasnya lebih tinggi yaitu menyesuaikan dengan keterjangkaun harga yaitu dengan memperhatikan kualitas dari produk sesuai dengan rasionalitas berkonsumsi. Sebaliknya mahasiswa yang memiliki persepsi harga yang kurang, mereka lebih cenderung bertindak impulsif, misalnya mereka melakukan pembelian baju tanpa mempertimbangkan apakah baju yang dibeli memiliki harga yang sesuai dengan kualitas yang didapatkan namun hanya tertarik keinginan sesaat karena tampilan produk baju yang ditampilkan sehingga lebih condong berperilaku impulsif dalam pembeliannya.

Dapat dikatakan bahwa perilaku pembelian secara impulsif dipengaruhi oleh faktor persepsi harga, karena pada dasarnya persepsi harga berpengaruh kuat pada konsumen karena pada saat akan memutuskan melakukan pembelian mereka akan mempertimbangkan dan mengevaluasi terlebih dahulu apakah harga dari suatu produk sesuai dengan kriteria atau tidak. Hal ini selaras dengan teori yang diungkapkan Simamora (2002:102) bahwasanya persepsi harga merupakan stimulus dari dalam diri konsumen untuk memutuskan melakukan pembelian dalam bentuk rasional atau sebaliknya. Namun tidak semua orang memiliki persepsi harga yang tinggi sehingga tidak menutup kemungkinan konsumen bertindak impulsif dalam melakukan pembelian. Ketika memutuskan melakukan pembelian mempersepsikan harga merupakan suatu proses yang penting serta rata-rata sebelum membeli konsumen akan menganalisis nilai gabungan diantara harganya dan kualitasnya. Kusdyah (25:2012) mengungkapkan bahwa tingkat rasionalitas konsumen dapat diukur dengan cara konsumen mempersepsikan harga sebelum terjadi transaksi pembelian yang sesungguhnya yaitu konsumen akan menimbang suatu harga apakah sesuai dengan internal reference yang diharapkan. Dengan mempersepsikan suatu harga konsumen dapat melakukan penetapan nilai dengan dasar membandingkan tingginya pengorbanannya dengan apa yang akan didapatkannya dari suatu produk tersebut. Sehingga dengan mempersepsikan suatu harga dengan tepat bisa dijadikan acuan untuk menghindari perilaku pembelian impulsif yang secara spontan tanpa memperhatikan harga yang menyebabkan pembelian tidak sesuai dengan kebutuhan. Persepsi harga dari beberapa sudut dikatakan sebagai faktor psikologis yang pengaruhnya penting sebagai tanggapan konsumen saat melakukan pembelian. Bahwasanya persepsi harga bisa menangkal perilaku pembelian impulsif yang tergantung dari segi reaksi konsumen melihat harga. Hal tersebut juga sejalan dengan Amryyanti, dkk. (2013) yang mengungkapkan bahwa persepsi harga merupakan sebuah penilaian terhadap suatu harga apakah dapat diterima atau tidak, dimana yang biasa menjadi patokan adalah kewajaran harga yang masuk akal untuk menetapkan keputusan.

Penelitian ini hasilnya berbanding terbalik pada penelitian yang dilakukan Dewi Aqliyah (2017) tentang pengaruh persepsi harga dengan perilaku pembelian impulsif, hasil penelitiannya adalah persepsi harga berpengaruh signifikan dan positif dengan perilaku pembelian impulsif. Hal tersebut artinya semakin tinggi persepsi harga pengaruhnya akan positif terhadap perilaku pembelian yang dilakukan mahasiswa secara impulsif. Hal tersebut karena cara pengukuran yang berbeda. Peneliti menggunakan cara pengukuran yang berbeda dengan penelitian Dewi Aqliyah. Pada penelitian peneliti menggunakan indikator kesadaran harga, potongan harga, dan keterkaitan harga dengan kualitas sedangkan pada penelitian Dewi Aqliyah menggunakan indikator keterjangkauan harga,daya saing harga, dan kesesuaian harga 
dengan manfaat. Oleh karena itu menyebabkan penelitian peneliti tidak selaras dengan penelitian yang dilakukan Setiawan Aditomo.

\subsection{Pengaruh Kontrol Diri Terhadap Perilaku Pembelian Impulsif Produk Baju Pada Mahasiswa S1 Pendidikan Ekonomi Universitas Negeri Malang Angkatan 2017}

Penelitian ini menerangkan hasil bahwa kontrol diri pengaruhnya signifikan dan mempunyai nilai negatif dengan perilaku pembelian impulsif. Hal ini menjelaskan bahwasanya mahasiswa yang kontrol dirinya baik akan cenderung rendah berperilaku impulsif dalam pembelian, hal tersebut dikarenakan kontrol diri yang baik berguna mengontrol dirinya terhindar pada hal-hal impulsif dalam pembelian dan mereka bersifat rasional dalam menentukan pembelian kebutuhannya. Pemaparan tersebut selaras pada teori yang diungkapkan Chaplin (2019) bahwasanya kontrol diri adalah kemampuan dalam menahan tingkah laku impulsif. Mempunyai tingkat kontrol diri yang baik dapat mengarahkan mahasiswa dalam mengendalikan keinginannya melakukan pembelian impulsif produk baju yang seharusnya tidak masuk dalam daftar kebutuhan namun hanya sebuah keinginan sesaat yang akhirnya menyebabkan kurangnya rasionalitas dalam pembelian. Hal tersebut juga diungkapkan Johansyah (2014:4) yang mengemukakan bahwa kontrol diri mampu menjauhkan diri dari impuls-impuls sesaat dan keinginan memenuhi kebutuhan yang bukan prioritas. Oleh karenanya mahasiswa yang baik kontrol dirinya akan terhindarkan dari perilaku pembelian yang tergolong impulsif.

Bahwasanya berdasarkan hasil deskriptif data penelitian mahasiswa S1 Pendidikan Ekonomi Universitas Negeri Malang Angkatan 2017 tergolong baik. Mahasiswa dengan kontrol diri yang baik dapat menangkal keinginannya melakukan pembelian dan mempertimbangkan beberapa hal sebelum melakukan pembelian. Sedangkan tingkat kontrol diri yang rendah sering terpacu berperilaku impulsif karena kurang mampu mengendalikan keinginannya.

Kontrol diri merupakan bentuk pengendalian perilaku yang hubunganya berkaitan dengan pengaturan emosi serta desakan-desakan dari dalam individu tersebut. Menurut Thompson (dalam Larasati dan Budiani, 2014:2) mengungkapkan bahwa kemantapan pada diri individu untuk mendapatkan hasil yang sesuai keinginannya melalui pengontrolan emosi serta desakan-desakan yang ada pada dirinya adalah unsur utama yang penting dalam pengontrolan diri. Melalui hal tersebut individu akan mampu melakukan penilaian terhadap dirinya. Tingkat pengendalian diri yang besar akan membuat individu condong untuk memperhatikan solusi yang benar dalam bertingkah laku sesuai dengan keberagaman keadaan. Pengendalian diri atau self control bisa diartikan sebagai pertimbanganpertimbangan sebelum memutuskan dalam melakukan suatu tindakan. Dapat dikatakan mahasiswa dengan kontrol diri tinggi maka ukuran intensitas pengendalian tingkah lakunya semakin baik juga. Kontrol diri juga dipengaruhi oleh usia dari seseorang, semakin bertambah usia individu maka tingkat kontrol dirinya semakin tinggi. Hal tersebut juga diungkapkan oleh Logue (dalam Mulyani, 2016) bahwa usia anak-anak cenderung melakukan tindakan impulsif dan bagi usia remaja keatas lebih mampu menunjukkan tingkat pengendalian diri atau kontrol diri. Melalui kontrol diri akan menjadikan perilaku pembelian mahasiswa menjadi terarah dan tidak hanya sekedar melakukan pembelian karena tampilan produk baju yang menarik. Hal tersebut sejalan dengan Ghufron dan Risnawati (2011:21) kontrol diri adalah kemampuan serta kepekaan individu dalam membaca situasi diri, menyeleksi antara informasi yang benar 
dan tidak benar untuk dirinya dan kemampuan melakukan pemilihan suatu tindakan yang sepadan pada apa yang diyakini individu tersebut. Pengendalian diri yang benar mampu mengarahkan mahasiswa agar dijauhkan atau dihindarkan pada tampilan produk baju yang mungkin memiliki potongan harga, model yang unik ataupun desain yang menarik, mereka akan mengendalikan diri mereka dengan memikirkan hal-hal yang lebih penting untuk diprioritaskan daripada pembelian sesaat yang nantinya akan merugikan.

Menurut Thalib (2017:107) mengungkapkan bahwa kontrol diri adalah pengendalian dorongan-dorongan, baik dari dalam maupun luar individu. Terdapat berbagai dorongan yang bisa ditangkal melalui kontrol diri dimana hal tersebut tergantung dengan bagaimana respon kita pada pengaruh dari luar yang tidak sesuai dengan keadaan kita pada saat itu seperti contoh pada saat kita berkunjung pada pusat perbelanjaan dan terdapat tampilan baju yang menarik dengan warna favorit kita namun kita belum membutuhkan baju tersebut, jadi kita bisa memutuskan untuk membeli baju tersebut atau tidak yang disesuaikan dengan keadaan kita saat itu. Melalui self control yang dimilikinya akan mudah dalam memutuskan serta pengambilan langkah perilaku yang terefektif dengan tujuan mendapatkan suatu hal yang sesuai keinginan dan dijauhkan dari dampak yang tidak sesuai keinginan. Menurut Rahayu, Srikandi (2015) mengungkapkan bahwa kontrol diri merupakan suatu aktivitas pengaturan tingkah laku dengan melakukan banyak pertimbangan sebelum bertindak. Selain itu juga menurut Otto, dkk.(dalam Helindawati, 2015 : 159) mengungkapkan bahwa kontrol diri adalah aktivitas pendorongan individu untuk berperilaku hemat ( bertujuan bisa mendapatkan manfaat) dan dalam perilaku pembelian impulsif bisa memberikan penekanan (pada kegiatan yang bertujuan hanya untuk bersenang-senang semata). Dengan mempertimbangkan berbagai hal sebelum bertindak seseorang akan mencoba untuk memberikan arahan pada dirinya sejalan dengan apa yang diinginkannya. Hal tersebut dapat juga dikatakan bahwa tingginya tingkat kontrol diri akan memperkuat pengontrolan diri individu tersebut pada perilakunya.

Penelitian ini mendapatkan hasil yang selaras dengan penelitian yang dilakukan Nuraeni (2015) terkait pengaruhnya kontrol diri dengan perilaku pembelian impulsif dimana hasil penelitiannya berpengaruh secara signifikan dan nilainya negatif antara kontrol diri dengan perilaku pembelian impulsif. Dimana hasil analisisnya adalah pada saat tingkat kontrol diri tinggi maka tingkat untuk berperilaku impulsifnya cenderung menurun

\subsection{Pengaruh Literasi Ekonomi Terhadap Perilaku Pembelian Impulsif Produk Baju Pada Mahasiswa S1 Pendidikan Ekonomi Universitas Negeri Malang Angkatan 2017}

Penelitian ini menunjukkan hasil yaitu adanya pengaruh signifikan dan bernilai negatif pada variabel literasi ekonomi dengan perilaku pembelian impulsif, yang artinya kecenderungan berperilaku impulsif pada pembelian mahasiswa yang memiliki pengetahuan menggunakan konsep dasar ekonomi dengan baik akan lebih kecil kemungkinannya hal ini disebabkan karena mahasiswa mampu untuk menerapkan pengetahuan yang telah diperolehnya dengan tepat dan baik. Ketika mahasiswa memiliki pengetahuan menggunakan konsep dasar ekonomi yang baik, mahasiswa dapat mengutamakan kebutuhan, bertindak sesuai dengan motif dan prinsip ekonomi, paham akan kelangkaan serta perilaku konsumsi yang benar sehingga mahasiswa dapat bertindak rasional dalam melakukan kegiatan konsumsi, oleh karena itu akan lebih mengarahkan mahasiswa untuk terhindar dari perilaku pembelian impulsif. Pandangan yang kurang serta terbelenggu tentang pengetahuan pada 
biaya atau manfaat dapat diatasi dengan literasi ekonomi. Pemaparan ini selaras dengan teori yang diungkapkan Sina (2012:135) bahwasanya literasi ekonomi dapat dijadikan alat mengubah tingkah laku seseorang yang awalnya kurang cerdas akan berubah lebih cerdas, seperti cara seseorang mengelola pendapatannya agar tetap bisa menabung, melakukan investasi, berjaga-jaga untuk masa yang akan datang, serta pemenuhan kebutuhan hidupnya.

Selanjutnya berdasarkan hasil deskriptif data penelitian mahasiswa S1 Pendidikan Ekonomi tergolong sangat baik. Hal tersebut karena mahasiswa yang literasi ekonominya baik lebih selektif dalam membeli barang yang sesuai dengan kebutuhan mereka sebagai seorang mahasiswa, mereka tidak mudah membeli tanpa sebuah perencanaan yang matang. Sebaliknya mahasiswa yang kurang baik dalam pemahaman menggunakan konsep dasar ekonomi, mereka akan lebih cenderung impulsif, misalnya pada saat di pusat perbelanjaan pada saat dari rumah mereka berencana untuk membeli buku untuk kebutuhan kuliah namun karena tergiur oleh dress yang memiliki desain menarik mereka lebih mengutamakan membeli dress dahulu dari pada buku yang seharusnya menjadi kebutuhan primer sebagai seorang mahasiswa.

Perilaku pembelian yang mengarah pada spontanitas dipengaruhi oleh faktor literasi ekonomi, karena pada dasarnya untuk pencapaian tujuan ekonomi yang benar, literasi ekonomi merupakan alat yang bisa digunakan. Akan tetapi setiap individu tidak mempunyai tingkat literasi ekonomi yang tinggi oleh karenanya kesempatan dalam mengerucutkan diri agar terhindar dari perilaku pembelian impulsif rendah. Menurut Kanserina,dkk. (2015) mengungkapkan bahwa kurangnya literasi ekonomi akan mempengaruhi transaksi pembelian hal tersebut disebabkan rendahnya pengetahuan dasar yang dibutuhkan untuk menguasai konsep ekonomi yang berkaitan dengan prinsip dan motif ekonomi yang tepat. Hal lain juga diungkapkan Melina dan Wulandari (2018:142) economic literacy merupakan situasi yang menjadi gambaran bahwa individu mempunyai kemampuan pemahaman akan permasalahan dasar ekonomi yang tepat dan benar, dengan begitu aktivitas ekonomi yang dilakukan individu tersebut akan terhindar dari perilaku pembelian impulsif dikarenakan tingkat selektifnya tinggi dalam pengambilan setiap keputusan dalam pembeliannya. Hal tersebut juga sejalan dengan pernyataan Murniatiningsih (2017:135) literasi ekonomi dapat diartikan sebagai keahlian untuk memecahkan permasalahan ekonomi, pembuatan alternatif pemecahan melalui pertimbangan manfaat dan biaya. Dengan memiliki pengetahuan dasar ekonomi yang tinggi dalam melakukan pembelian tidak hanya tergiur oleh tampilan dari produk namun tetap memperhitungkan biaya dan manfaat yang digunakan sehingga tidak memberikan dampak merugikan setelah membelinya, karena dengan literasi ekonomi pembelian akan didasarkan akan prinsip ekonomi yang tepat bukan hanya pembelian tanpa perencanaan atau impulsif yang bisa merusak kebutuhan primer yang sudah direncanakan.

Penelitian ini mendapatkan hasil yang selaras pada hasil penelitian Desy Choirunisa (2021) yaitu tentang literasi ekonomi dengan perilaku pembelian impulsif yang hasil penelitiannya menerangkan adanya pengaruh signifikan serta bernilai negatif antara literasi ekonomi dengan perilaku pembelian impulsif. Hal ini artinya literasi ekonomi yang tinggi pada mahasiswa akan menurunkan tingkat perilaku pembelian impulsifnya. 


\subsection{Pengaruh Persepsi Harga, Kontrol Diri dan Literasi Ekonomi Terhadap Perilaku Pembelian Impulsif Produk Baju Pada Mahasiswa S1 Pendidikan Ekonomi Universitas Negeri Malang Angkatan 2017}

Penelitian ini menunjukkan hasil bahwasanya perilaku pembelian impulsif produk baju mahasiswa S1 pendidikan ekonomi universitas negeri malang angkatan 2017 dipengaruhi oleh persepsi harga, kontrol diri, dan literasi ekonomi. Pengujian hipotesisnya didapatkan bahwa setiap variabel independen pengaruhnya negatif terhadap variabel dependen. Hal tersebut artinya semakin tinggi tingkat persepsi harga, kontrol diri, dan literasi ekonomi akan menurunkan perilaku pembelian secara impulsif pada produk baju. Pada penganalisisan data didapatkan hasil bahwa terdapat pengaruh secara simultan antara persepsi harga, kontrol diri, dan literasi ekonomi terhadap perilaku pembelian impulsif produk baju mahasiswa S1 pendidikan ekonomi universitas negeri malang angkatan 2017. Besarnya nilai kontribusi yang diberikan variabel persepsi harga, kontrol diri, dan literasi ekonomi secara simultan (bersamasama) yaitu sejumlah $61,5 \%$ dan sisanya $38,5 \%$ terdapat faktor lain yang mempengaruhi diluar penelitian ini.

Faktor yang memiliki pengaruh paling tinggi merupakan persepsi harga dikarenakan konsumen sebelum memutuskan transaksi pembeliannya akan mempersepsikan terlebih dahulu harganya. Pengaruh kuat konsumen dalam melakukan pembelian adalah sebuah persepsinya terhadap harga. Persepsi harga adalah suatu rangkaian penting dalam pembelian sebelum memutuskan pembelian, oleh karena itu konsumen yang cenderung memiliki persepsi harga yang baik sebelum membeli akan memperhatikan terlebih dahulu faktor-faktor yang menurutnya layak dibeli. Konsumen yang memiliki persepsi harga yang baik akan memperhatikan perbandingan harga, kualitas dan manfaat. Bukan hanya sekedar melakukan pembelian tanpa perencanaan yang matang. Menurut teori Kotler dan Amstrong terdapat indikator persepsi harga antara lain harga yang masih dapat dijangkau, keselarasan harga dengan kualitas produknya, serta harga selaras dengan manfaatnya. Oleh karena itu perilaku pembelian impulsif kemungkinan terjadi kecil apabila mahasiswa mampu menangkal keinginan sesaat yang terjadi secara spontan dengan memiliki persepsi harga yang baik.

Terdapat faktor lain yang mempengaruhi perilaku pembelian impulsif produk baju mahasiswa yaitu kontrol diri yang dimiliki mahasiswa tersebut. Mahasiswa dengan pengontrolan diri yang benar dan tepat dikatakan mempunyai kemampuan mengendalikan diri dari berbagai hal yang berasal dari diri sendiri maupun lingkungan luar. Salah satunya mengontrol keinginan dalam diri, seperti ketika dalam pusat perbelanjaan melihat model baju yang saat ini sedang trend dan memiliki desain yang menarik pada awalnya ada hasrat untuk melakukan pembelian karena ingin terlihat mengikuti perubahan mode baju, namun karena kontrol diri yang dimiliki kuat dan memikirkan bahwa baju tersebut sebenarnya bukanlah kebutuhan yang utama harus dipenuhi maka keinginan untuk bertindak impulsif terhindar karena kontrol diri yang dimiliki. Hal tersebut juga diungkapkan oleh Averill (dalam Marsela dan Supriatna, 2019:67) mengemukakan bahwa kontrol diri dapat mengarahkan individu untuk berkegiatan yang dampaknya positif yaitu dengan artian bahwa kontrol diri menjadikan individu tersebut perilakunya tersusun, terarah, teratur serta terbimbing dengan jelas dan benar.

Faktor lain yang berpengaruh pada perilaku pembelian impulsif adalah literasi ekonomi. Dimana literasi ekonomi menunjukkan seberapa besar pemahaman seseorang terhadap 
pengetahuan dasar ekonomi. Dimana pengetahuan tersebut dapat dijadikan acuan dalam kegiatan ekonomi terutama dalam kegiatan pembelian. Mahasiswa yang memiliki kecenderungan literasi ekonomi rendah mereka akan cenderung berperilaku konsumtif. Perilaku konsumtif menyebabkan hilangnya rasionalitas pembelian sehingga lebih sering memunculkan keinginan untuk membeli secara spontan, reflek, dan tidak ada rencana yang jelas atau disebut dengan keinginan untuk membeli secara impulsif atau perilaku pembelian impulsif. Selaras dengan hal tersebut Haryani dan John (2015:6) mengungkapkan bahwasanya perilaku konsumtif menyebabkan beberapa perilaku yang meliputi pembelian impulsif, pemborosan, dan hanya mencari kesenangan semata saja. Oleh karena hal tersebut maka literasi ekonomi yang baik sangat diperlukan untuk mahasiswa dengan tujuan untuk menghindarkan diri dari perilaku pembelian impulsif. Sebaliknya literasi ekonomi yang rendah akan lebih rentan menaikkan tingkat perilaku pembelian impulsif pada mahasiswa.

\section{Simpulan}

\subsection{Kesimpulan}

Adanya pengaruh negatif antara persepsi harga terhadap perilaku pembelian impulsif mahasiswa S1 Pendidikan Ekonomi Universitas Negeri Malang Angkatan 2017. Hal ini menerangkan bahwasanya mahasiswa yang mempunyai persepsi harga yang baik terhadap produk baju yang akan dibeli akan cenderung bertindak rasional dalam pembelian, sebaliknya mahasiswa yang memiliki persepsi harga kurang baik akan rentan terpengaruh melakukan pembelian impulsif produk baju.

Adanya pengaruh negatif antara kontrol diri terhadap perilaku pembelian impulsif produk baju mahasiswa S1 Pendidikan Ekonomi Universitas Negeri Malang Angkatan 2017. Hal tersebut menunjukkan bahwa mahasiswa yang mempunyai kontrol diri yang baik akan lebih terhindar dari keinginan untuk melakukan pembelian produk baju secara impulsif, Sebaliknya kurangnya kontrol diri yang dimiliki oleh mahasiswa menyebabkan mahasiswa kurang bisa mengendalikan tingkah lakuknya sehingga lebih berperilaku impulsif.

Adanya pengaruh negatif antara literasi ekonomi terhadap perilaku pembelian impulsif mahasiswa S1 Pendidikan Ekonomi Universitas Negeri Malang Angkatan 2017. Hal tersebut menerangkan bahwasanya tingkat literasi ekonomi yang benar akan lebih mengarahkan pada perilaku pembelian yang rasional, sebaliknya tingkat literasi ekonomi yang rendah akan mudah mengarahkan mahasiswa melakukan pembelian impulsif.

Persepsi harga, kontrol diri, dan literasi ekonomi secara simultan memiliki pengaruh terhadap perilaku pembelian impulsif produk baju mahasiswa S1 Pendidikan Ekonomi Universitas Negeri Malang Angkatan 2017. Variabel yang memiliki pengaruh paling tinggi adalah persepsi harga.

\subsection{Saran}

Berdasarkan hasil penelitian, Peneliti memberikan saran kepada berbagai pihak, yang pertama bagi mahasiswa yang sudah memiliki persepsi harga, kontrol diri, dan literasi ekonomi yang baik diharapkan tetap dipertahankan dan lebih baik ditingkatkan karena memiliki dampak yang baik yaitu dijauhkan dari perilaku pembelian impulsif yang membuat rugi diri sendiri karena dapat menyebabkan tidak stabilnya pemenuhan kebutuhan yang 
seharusnya. Kedua untuk peneliti lainnya selanjutnya yang akan melaksanakan penelitian yang serupa disarankan memperluas variabel-variabel lain (seperti variabel kualitas produk, citra merek, dan masih banyak lagi) karena banyak variabel lain yang mempengaruhi perilaku pembelian impulsif.

\section{Daftar Rujukan}

Aqiliyyah, D. (2017). Analisis pengaruh kualitas informasi, harga dan kualitas produk terhadap pembelian impulsif dalam belanja online menurut perspektif ekonomi Islam (Studi Pada Mahasiswa Fakultas Ekonomi Dan Bisnis Islam UIN Raden Intan Lampung Angkatan 2015) (Doctoral dissertation, UIN Raden Intan Lampung).

Sukaatmadja, i. P. G., \& amryyanti, r. (2013). Pengaruh Kualitas Layanan, Produk, dan Kewajaran Harga terhadap Kepuasan dan Loyalitas Pelanggan pada Lnc Skin Care Singaraja. E-Jurnal Ekonomi dan Bisnis Universitas Udayana, 44677.

Anjani, N. L. G. G. (2012). Pengaruh Fashion Involvement, Emosi Positif dan Hedonic Consumption Tendency Terhadap Pembelian Impulsif di Department Store (Doctoral dissertation, UAJY).

Chaplin, J. P., \& Kartono, K. (2019). Kamus lengkap psikologi.

Choirunnisa, D. (2021). Perilaku Pembelian Impulsif: Seberapa Besar Peran Gaya Hidup dan Literasi Ekonomi? Jurnal Pendidikan Ekonomi, 14(1), 61-70.

Clover, V. T. (1950). Relative importance of impulse-buying in retail stores. Journal of marketing, 15(1), 66-70.

Fitrawaty, M. S., \& Hasibuan, R. D. A. (2015). Pengaruh Literasi Ekonomi Dan Kelompok Teman Sebaya Terhadap Perilaku Pembelian Impulsif Untuk Produk Fashion Pada Mahasiswa Pendidikan Ekonomi Angkatan 2015 Di Fakultas Ekonomi Universitas Negeri Medan. Jurnal Ekodik: Ekonomi Pendidikan, 6 (7).

Ghufron, M. N., \& Rini Risnawita, S. (2010). Teori-Teori Psikologi, Yogyakarta. Ar-Ruzz Media.

Harjati, L., \& Venesia, Y. (2017). Pengaruh kualitas layanan dan persepsi harga terhadap kepuasan pelanggan pada maskapai penerbangan Tiger Air Mandala. E-Journal Widya Ekonomika, 1(1), 64-74.

Haryani, I., \& Herwanto, J. (2016). Hubungan konformitas dan kontrol diri dengan perilaku konsumtif terhadap produk kosmetik pada mahasiswi. Jurnal Psikologi, 11(1), 5-11.

Herlindawati, D. (2017). Pengaruh kontrol diri, jenis kelamin, dan pendapatan terhadap pengelolaan keuangan pribadi mahasiswa pascasarjana Universitas Negeri Surabaya. Jurnal ekonomi pendidikan dan kewirausahaan, 3(2), 158-169.

Hetharie, J. A. (2012). Impulse Buying Tendency: Studi Pada Konsumen Matahari Departement Store Kota Ambon. IQTISHODUNA.

Hoyri, Imam. (2014). Kontrol Diri dan Perilaku Konsumtif pada Siswa SMA Ditinjau dari Lokasi Sekolah. Jurnal Online Psikologi. Vol. 2 No.1.hlm. 46-61.

Johansyah. (2014). Pengaruh self-control dan self-concept terhadap perilaku modeling pada remaja berkaitan dengan trend berbusana dari Korea. UIN. Jakarta.

Kanserina, D., Haris, I. A., \& Nuridja, I. M. (2015). Pengaruh literasi ekonomi dan gaya hidup terhadap perilaku konsumtif mahasiswa jurusan pendidikan ekonomi universitas pendidikan ganesha tahun 2015. Jurnal Pendidikan Ekonomi Undiksha, 5(1).

Kaura, V. (2012). A link for perceived price, price fairness and customer satisfaction. Pacific Business Review International, 5(6), 84-88.

Kotler, P. Amstrong (2001) Prinsip-Prinsip Pemasaran. Erlangga, Jakarta.

Kusdyah, I. (2012). Persepsi Harga, Persepsi Merek, Persepsi Nilai, dan Keinginan Pembelian Ulang Jasa Clinic Kesehatan (Studi Kasus Erha Clinic Surabaya). Jurnal Manajemen Pemasaran, 7(1), 25-32.

Larasati, M. A., \& Budiani, M. S. (2014). Mahasiswi psikologi universitas negeri Surabaya yang melakukan pembelian secara online.

Marsela, R. D., \& Supriatna, M. (2019). Konsep Diri: Definisi dan Faktor. Journal of Innovative Counseling: Theory, Practice, and Research, 3(02), 65-69. 
Melina, A., \& Wulandari, S. (2018). Pengaruh Literasi Ekonomi dan Gaya Hidup Terhadap Perilaku Konsumtif Mahasiswi Pendidikan Ekonomi STKIP YPM Bangko. SJEE: Scientific Journals of Economic Education, 2(1), 141-152.

Mulyani. (2016). Pengaruh Financial Literacy, Status Sosial Ekonomi Orang Tua, dan Kelompok Teman Sebaya Terhadap Perilaku Menabung Siswa Kelas XI IPS SMA Negeri 8 Malang Tahun Ajaran 2015/2016. Skripsi tidak diterbitkan: Universitas Negeri Malang

Murniatiningsih, E. (2017). Pengaruh literasi ekonomi siswa, hasil belajar ekonomi, dan teman sebaya terhadap perilaku konsumsi siswa SMP Negeri di Surabaya Barat. Jurnal Ekonomi Pendidikan dan Kewirausahaan, 5(1), 127-156.

Nuraeni. (2015). Pengaruh Literasi Ekonomi, Kelompok Teman Sebaya Dan Kontrol Diri Terhadap Perilaku Pembelian Impulsif Untuk Produk Fashion Pada Mahasiswa Fakultas Ekonomi Universitas Negeri Yogyakarta. Journal of Banking and Finance.

Oktavia. (2019). Pengaruh Literasi Ekonomi Dan Persepsi Teman Sebaya Terhadap Perilaku Pembelian Impulsif Untuk Produk Fashion Di Online Shop Pada Siswa Kelas X Program Keahlian Pemasaran di SMK 17 Pare Kabupaten Kediri, 1-8.

Peter, Paul J., Jerry C. Olson. (2010). Consumer Behavior \& Marketing Strategy. 9th Edition. McGraw Hill.

Pratiwi, I. (2017). Pengaruh Literasi Ekonomi, Kelompok Teman Sebaya dan Kontrol Diri terhadap Perilaku Pembelian Impulsif untuk Produk Fashion Di Online Shop pada Mahasiswa Jurusan Pendidikan Ekonomi Undiksha. Jurnal Pendidikan Ekonomi Undiksha, 9(1), 98-107.

Rahayu, n. S. (2019). Hubungan antara konformitas dalam peer group dan kontrol diri dengan perilaku bullying pada siswa kelas xi dan xii di SMA Wachid hasyim 1 Surabaya (Doctoral dissertation, Universitas Muhammadiyah Surabaya).

Rahmasari, L. (2010). Menciptakan Impulse Buying. Majalah ilmiah informatika, 1(3).

Rook, D. W., \& Fisher, R. J. (1995). Normative influences on impulsive buying behavior. Journal of consumer research, 22(3), 305-313.

Setyaningrum\& Harsono. (2018). Implementasi Literasi Ekonomi dan Tingkat Konsumtifitas Mahasiswa Pendidikan Akuntansi FKIP UMS Angkatan 2014 Simamora, Bilson. Panduan Riset Perilaku Konsumen. Gramedia. Jakarta. 2002.

Sina, P. G. (2012). Analisis literasi ekonomi. Jurnal Economia, 8(2), 135-143.

Sugiono. (2018). Metode Penelitian Kuantitatif, Kualitatif, dan R\&D. Bandung: Alfabeta

Syahid, M. S. (2019). Pengaruh kualitas produk, promosi, persepsi harga, dan lokasi terhadap keputusan pembelian di toko riskmi sport gresik (Doctoral dissertation, Untag Surabaya).

Thalib, S. B. (2017). Psikologi pendidikan berbasis analisis empiris aplikatif. Prenada Media.

Verhagen, T., \& Van Dolen, W. (2011). The influence of online store beliefs on consumer online impulse buying: A model and empirical application. Information \& Management, 48(8), 320-327. 